\title{
An Internal Evaluation of Higher Education Curriculum Using Data Transformation Model
}

\author{
Michael B. Cahapay \\ ${ }^{1}$ College of Education, Mindanao State University Fatima, General Santos City, \\ 9500, South Cotabato, Philippines \\ Corresponding email: mbcahapay@up.edu.ph
}

DOI: https://doi.org/10.37134/ajatel.vol10.2.1.2020

Received: 24 April 2020; Accepted: 01 June 2020; Published: 03 July 2020

Cite this article (APA): Cahapay, M. B. (2020). An internal evaluation of higher education curriculum using data transformation model. Asian Journal of Assessment in Teaching and Learning, 10(2), 1-9. https://doi.org/10.37134/ajatel.vol10.2.1.2020

\begin{abstract}
A curriculum does not exist in a void; internal members play a key role in responding to the different forces that continually shape it. One of the approaches to evaluation is through internal evaluation from the perspective of the inside members who work with the curriculum. However, the internal evaluation may pose restricted evaluation due to the innate subjective human judgment. Considering these contexts, this paper performed a pilot internal evaluation of a selected aspect of a higher education curriculum using a triangulation mixed method design called the data transformation model. Based on the results, the evaluation using the data transformation model probed important points of agreement and discrepancy in the data sets. The implications for evaluation theory and curriculum practice are discussed. It is suggested that an extension of the current formative internal evaluation continuing the tradition of data transformative model but progressively focusing on larger aspects of the curriculum should be further conducted.
\end{abstract}

Keywords: Internal Evaluation, Curriculum Studies, Higher Education, Mixed Method, Data Transformation Model

\section{INTRODUCTION}

Curriculum programs are constantly shaped by forces that surround it. These forces in the curriculum development (Skilbeck, 1984; Giacquinta, 1998; Peretz, 2003; Makaran, 2015) bring challenges that overwhelm teachers in the school. As key players accountable for the continuous development of the curriculum, teachers should give primary attention as to how these forces are being addressed in the curriculum.

An evaluation approach that focuses on the role of internal members and their accountability to the program is the internal evaluation. It is an evaluation that involves the use of internal members, contrary to external experts, to evaluate programs of direct relevance to an organization. Internal evaluation in schools can be performed by a group of school administrators and teachers (Clifford, 1987; Love, 1998; Nevo, 2001). However, internal evaluation comes also with challenges because, while it ensures ownership and accountability, it may also be prone to restricted judgments. After all, internal members are also workers who are vassal to the pressures of the organizational sphere (Kennedy, 1983).

A design that may answer this problem is the mixed method design, a type of research in which a researcher or team of researchers combine elements of qualitative research and quantitative research approaches (Johnson \& Christensen, 2017) to ultimately achieve multiple validities legitimation (Onwuegbuzie \& Johnson 2006). It has a purpose of triangulation which intends to look for convergence and corroboration of results from different methods (Greene, Caracelli, \& Graham, 2007). This particular feature of mixed method design can reduce, if not eliminate, the subjectivism often related to internal evaluation. 
One of the particular mixed method designs is the data transformation model (Creswell, 2011). This model follows a separate collection for quantitative data and qualitative data from the same participants. Then one of the data types in the initial stage is converted into the other data type, allowing for mixing of both data in the following stage. This method is hinged on the triangulation of data from the same source, which appears to address the possible slanted judgment potential in internal evaluation. Tyler (2005) has extensively discussed the nature of internal evaluation but methods to compensate with its main weakness have not been offered.

A survey of researches show that internal evaluation has been conducted in education and curriculum (Yeung, 2010; Technological Educational Institute of Athens, 2010; Vajargah, Babadi, \& Hajatmand, 2014; Kyoto University Graduate School of Management, 2015; Norman \& Sherwood, 2015; Sellwood-Davis; 2016; Yusa, Hynie, \& Mitchell, 2016; International Education Systems, 2017; International University of Sarajevo, 2018). However, considering the main weakness of the internal evaluation approach discussed earlier, the data transformation model as an evaluation method has not been tested.

This present study will be significant to the evaluation theory and curriculum practice. The result will produce significant knowledge regarding the methods that may be used to offset the weaknesses innate to internal evaluations. It will also provide practical insights into primary curriculum workers as to how the current curriculum responds to the forces that shape it.

Thus, this paper performed a pilot internal evaluation of a selected aspect of a higher education curriculum using a triangulation mixed method design called the data transformation model. It specifically addressed the following questions:

1. What is the level of responsiveness to the forces of the curriculum?

2. How does the converted qualitative data reconcile with the quantitative data?

3. Is the data transformation model effective in addressing the innate weakness of internal evaluation?

\section{METHOD}

\section{Design}

This study entailed a mixed method research design for curriculum evaluation. It specifically employed a data transformation model. This model involves the independent collection and exploration of quantitative and qualitative data types. However, after the early analysis, a conversion of one data type into the other data type occurs. This approach is attained through either quantifying or qualifying the results. This conversion allows the data to be mixed during the analysis stage and facilitates the contrast of one data type coming from two different data sets (Creswell, 2011).

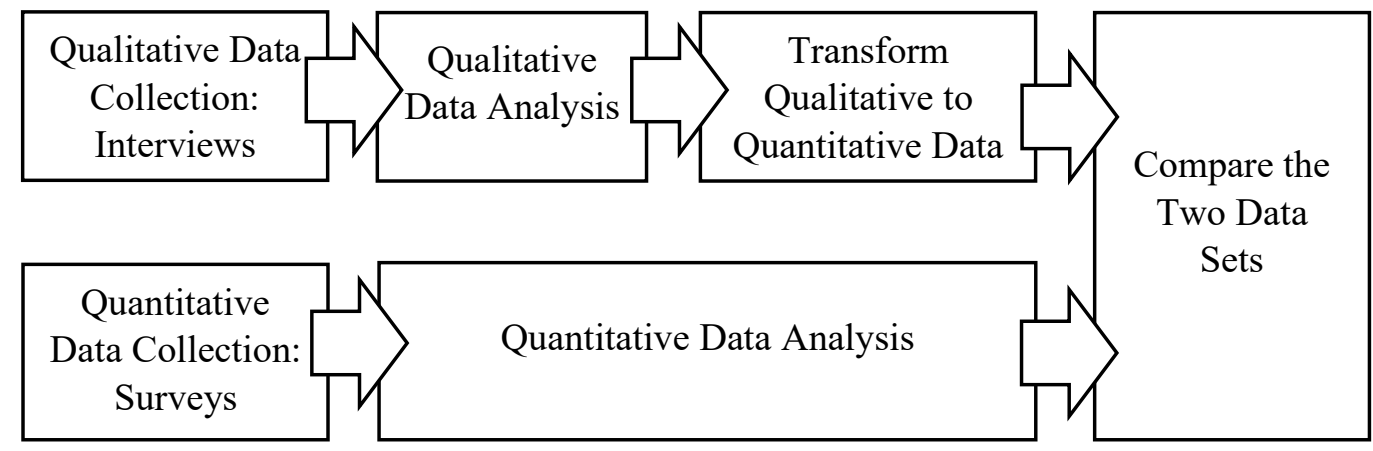

Figure 1. The research design of this study 


\section{Sample}

This study employed purposive sampling to select the participants of this study. Purposive sampling is defined by Suen, Huang, and Lee (2014) as a technique in which participants are selected with the prospect that each of them will be able to provide the needed data to the study. Considering also the suggestion of Nevo (2001), an internal evaluation in schools can be performed by a group of school administrators and teachers. Hence, in this study, the college dean, department chairperson and three professors were involved. They were selected based on their capacity to furnish information about the responsiveness of the curriculum to the internal and external influences. They were involved in the continuous development of the curriculum through direct work experience.

\section{Venue}

This study was conducted in a higher education institution established for more than thirty years in Mindanao, Philippines. As an institution of higher learning with a special mandate to offer responsive programs to promote development to its community, it is important to evaluate the extent to which its programs respond to the internal and external influences that continuously shape its features.

\section{Data Collection Techniques}

One of the data collection techniques employed in this study is the interview. It was conducted to gather information on how each participant evaluates the curriculum based on policy responsiveness through frequencies of relevant utterances. Furthermore, a set of statements complementing the themes that emerged in the interview were developed into items in a questionnaire. This questionnaire, which was content validated by colleagues, was used in another data collection technique in this study which is a survey. This technique aimed to collect information on how each participant evaluates the curriculum based on its responsiveness through the rating of items in a scale.

\section{Data Analysis Techniques}

A technique used to examine the qualitative data of this study is thematic analysis. It is a technique that uses analysis of utterances, transforming them into codes, then grouping them into themes, and streamlining the data to answer the research question (Moore \& McCabe, 2005). This technique was useful in initially generating the themes used for the subsequent analysis in this research.

Another data analysis technique used in this study was content analysis. Content analysis refers to the method of detailed inspection of documents created across an extensive collection of practices, taking a variety of forms from the written word to the image (Jupp, 2006). This technique was used to examine the frequency of participants uttering code under a theme.

On the other hand, to describe the level of responsiveness of the curriculum, descriptive statistics were used. Descriptive statistics describe the basic characteristics of the research information collected (Trochim, 2006). Specifically, the frequency count and percentage rate were applied to convert the codes from the interviews into quantitative data while the weighted mean and percentage rate were employed for the ratings from the surveys.

\section{RESULTS}

The utterances were analyzed to arrive at themes. The result of the analysis provided seven themes of internal and external forces considered in accounting for the quality of the curriculum.

Table 1. Themes generated from the interviews

\begin{tabular}{|l|l|}
\hline \multicolumn{1}{|c|}{ Sample Codes } & \multicolumn{1}{c|}{ Theme } \\
\hline $\begin{array}{l}\text { One must bear the mission and vision of the University in } \\
\text { developing the curriculum. }\end{array}$ & $\begin{array}{l}\text { The curriculum reflects the vision, } \\
\text { mission, and values of the university. }\end{array}$ \\
\hline
\end{tabular}




\begin{tabular}{|c|c|}
\hline $\begin{array}{l}\text { I articulate the outcomes of the lesson to the vision and mission of } \\
\text { the University. }\end{array}$ & \\
\hline $\begin{array}{l}\text { I consider the goals of the College and the objectives of the } \\
\text { Department in planning my lessons. }\end{array}$ & \multirow{2}{*}{$\begin{array}{l}\text { The curriculum mirrors the goals and } \\
\text { objectives of the college and } \\
\text { department. }\end{array}$} \\
\hline $\begin{array}{l}\text { I usually attempt to explain the thick line of the relativity of the } \\
\text { lessons to the College goals and Department objectives. }\end{array}$ & \\
\hline $\begin{array}{l}\text { The curriculum already realigned its standards set by the } \\
\text { Commission. }\end{array}$ & \multirow[t]{2}{*}{$\begin{array}{l}\text { The curriculum satisfies the standards } \\
\text { of the highest regulating body. }\end{array}$} \\
\hline It followed the mandated rules and policies set by the Commission. & \\
\hline $\begin{array}{l}\text { Ifollow the } 21 \text { st-century skills framework because I think this } \\
\text { paradigm makes our students globally competitive. }\end{array}$ & \multirow{2}{*}{$\begin{array}{l}\text { The curriculum promotes the } \\
\text { development of twenty-first century } \\
\text { skills. }\end{array}$} \\
\hline $\begin{array}{l}\text { These elements prepare and provide a balanced and holistic } \\
\text { development of learners with } 21 \text { st-century skills. }\end{array}$ & \\
\hline $\begin{array}{l}\text { The Board Examination results are taken into consideration in } \\
\text { designing the learning assessment. }\end{array}$ & \multirow{2}{*}{$\begin{array}{l}\text { The curriculum aligns with the } \\
\text { competencies measured in the board } \\
\text { examination. }\end{array}$} \\
\hline $\begin{array}{l}\text { A benchmark of our good curriculum is based on its Board } \\
\text { Examination results. }\end{array}$ & \\
\hline $\begin{array}{l}\text { I find it necessary to align the lessons I teach to the skills } \\
\text { demanded by the market. }\end{array}$ & \multirow[t]{2}{*}{$\begin{array}{l}\text { The curriculum complements the skills } \\
\text { needed in the education industry. }\end{array}$} \\
\hline $\begin{array}{l}\text { The industry is one of the bodies that we consider in curriculum } \\
\text { planning. }\end{array}$ & \\
\hline $\begin{array}{l}\text { The submission of the curriculum to the Accreditation Council } \\
\text { redirected its standards. }\end{array}$ & \multirow{2}{*}{$\begin{array}{l}\text { The curriculum incorporates the } \\
\text { standards required by the accreditation } \\
\text { council. }\end{array}$} \\
\hline $\begin{array}{l}\text { The Accreditation Council is important to ensure that our } \\
\text { curriculum is assured of quality. }\end{array}$ & \\
\hline
\end{tabular}

These themes express that the curriculum:

1. reflects the vision, mission, and values of the university;

2. mirrors the goals and objectives of the college and department;

3. satisfies the standards of the highest regulating body;

4. promotes the development of twenty-first century skills;

5. aligns with the competencies measured in the board examination;

6. complements the skills needed in the education industry; and

7. incorporates the standards required by the accreditation council.

These themes capture how the curriculum, through the school administrators and teachers, is addressing the internal and external forces. These themes were further transformed into quantitative data in the following stage of data analysis.

Table 2. Descriptive statistics of related codes from interviews

\begin{tabular}{|l|c|c|}
\hline \multicolumn{1}{|c|}{ Theme } & f & \% \\
\hline 1.) The curriculum reflects the vision, mission, and values of the university. & 4 & $80 \%$ \\
\hline $\begin{array}{l}\text { 2.) The curriculum mirrors the goals and objectives of the college and } \\
\text { department. }\end{array}$ & 3 & $60 \%$ \\
\hline 3.) The curriculum satisfies the standards of the highest regulating body. & 3 & $60 \%$ \\
\hline 4.) The curriculum promotes the development of twenty-first century skills. & 2 & $40 \%$ \\
\hline $\begin{array}{l}\text { 5.) The curriculum aligns with the competencies measured in the board } \\
\text { examination. }\end{array}$ & 2 & $40 \%$ \\
\hline 6.) The curriculum complements the skills needed in the education industry. & 2 & $40 \%$ \\
\hline $\begin{array}{l}\text { 7.) The curriculum incorporates the standards required by the accreditation } \\
\text { council. }\end{array}$ & 1 & $20 \%$ \\
\hline
\end{tabular}

The qualitative data generated from the interviews was transformed into quantitative data. A quantitative content analysis of the utterances of the participants was conducted to determine the frequency of participants uttering codes related to the theme. The results show that the participants have a favorable evaluation that the curriculum reflects the mission and vision of the university $(80 \%)$; 
mirrors the goals and objectives of the college and department $(60 \%)$; and satisfies the standards prescribed by the highest regulating body $(60 \%)$. On the other hand, the participants have a somewhat favorable evaluation that the curriculum promotes twenty-first century skills $(40 \%)$; aligns with the competencies measured in the board examination (40\%); complements the skills needed in the education industry (40\%); and incorporates the standards required by the accreditation council (20\%).

Table 3. Descriptive statistics of ratings from surveys

\begin{tabular}{|l|c|c|}
\hline \multicolumn{1}{|c|}{ Indicators } & M & \% \\
\hline 1.) The curriculum reflects the vision, mission, and values of the university. & 3.40 & $85 \%$ \\
\hline 2.) The curriculum mirrors the goals and objectives of the college and department. & 3.40 & $85 \%$ \\
\hline 3.) The curriculum satisfies the standards of the highest regulating body. & 3.40 & $85 \%$ \\
\hline 4.) The curriculum promotes the development of twenty-first century skills. & 3.20 & $80 \%$ \\
\hline 5.) The curriculum aligns with the competencies measured in the board examination. & 3.20 & $80 \%$ \\
\hline 6.) The curriculum complements the skills needed in the education industry. & 3.40 & $85 \%$ \\
\hline 7.) The curriculum incorporates the standards required by the accreditation council. & 3.00 & $75 \%$ \\
\hline
\end{tabular}

The quantitative data obtained from the surveys were tabulated. The ratings of each participant per item were added. Then the weighted mean and percentage rate were computed.

The results revealed that the participants have a favorable rating that the curriculum reflects the mission and vision of the university (85\%); mirrors the goals and objectives of the college and department (85\%); satisfies the standards prescribed by the highest regulating body $(85 \%)$; and complements the skills needed in the education industry (85\%). Furthermore, it appeared that the participants have a favorable rating that the curriculum promotes twenty-first century skills $(80 \%)$; aligns with the competencies measured in the board examination $(80 \%)$; and incorporates the recommendations of the accreditation council (75\%).

Table 4. Comparison of converted qualitative data and quantitative data

\begin{tabular}{|l|c|c|c|c|}
\hline \multicolumn{1}{|c|}{ Theme / Indicator } & Qual & Quan & $\begin{array}{c}\text { Level of } \\
\text { Agreement }\end{array}$ & $\begin{array}{c}\text { Evaluative } \\
\text { Description }\end{array}$ \\
\hline $\begin{array}{l}\text { 1.) The curriculum reflects the vision, mission, } \\
\text { and values of the university. }\end{array}$ & $80 \%$ & $85 \%$ & $94.12 \%$ & Quan and Qual agree \\
\hline $\begin{array}{l}\text { 2.) The curriculum mirrors the goals and } \\
\text { objectives of the college and department. }\end{array}$ & $60 \%$ & $85 \%$ & $70.59 \%$ & Quan and Qual agree \\
\hline $\begin{array}{l}\text { 3.) The curriculum satisfies the standards of the } \\
\text { highest regulating body. }\end{array}$ & $60 \%$ & $85 \%$ & $70.59 \%$ & Quan and Qual agree \\
\hline $\begin{array}{l}\text { 4.) The curriculum promotes the development of } \\
\text { twenty-first century skills. }\end{array}$ & $40 \%$ & $80 \%$ & $50.00 \%$ & $\begin{array}{l}\text { Quan and Qual do not } \\
\text { reconcile }\end{array}$ \\
\hline $\begin{array}{l}\text { 5.) The curriculum aligns with competencies } \\
\text { measured in the board examination. }\end{array}$ & $40 \%$ & $80 \%$ & $50.00 \%$ & $\begin{array}{l}\text { Quan and Qual do not } \\
\text { reconcile }\end{array}$ \\
\hline $\begin{array}{l}\text { 6.) The curriculum complements the skills needed } \\
\text { in the education industry. }\end{array}$ & $40 \%$ & $85 \%$ & $47.06 \%$ & $\begin{array}{c}\text { Quan and Qual do not } \\
\text { reconcile }\end{array}$ \\
\hline $\begin{array}{l}\text { 7.) The curriculum incorporates standards } \\
\text { required by the accreditation council. }\end{array}$ & $20 \%$ & $75 \%$ & $26.68 \%$ & $\begin{array}{c}\text { Quan and Qual do not } \\
\text { reconcile }\end{array}$ \\
\hline
\end{tabular}

Qual= converted qualitative data into quantitative data; Quan= quantitative data; $N=5$

The converted qualitative data and quantitative data were compared. The comparison between the two data sets shows the points of agreement and discrepancy in the themes or indicators. The theme or indicator that drew the strongest agreement between the converted qualitative data and quantitative data states that the curriculum reflects the mission and vision of the university $(94.12 \%)$. It was also noted that there was a strong agreement in the theme or indicator that the curriculum mirrors the goals and objectives of the college and department $(70.59 \%)$; and satisfies the standards prescribed by the highest regulating body $(70.59 \%)$. 
However, the converted qualitative data and quantitative data did not reconcile on the themes or indicators that the curriculum includes twenty-first century skills $(50.00 \%)$; aligns with the competencies measured in the board examination (50.00\%); and complement the skills needed in the education industry $(47.06 \%)$.

Lastly, it can be notably gleaned from the result that the converted qualitative data and quantitative data did not most reconcile on the theme or indicator that the curriculum incorporates the recommendations of the accreditation council (26.68\%).

\section{DISCUSSION}

This study found out different influential forces that inside members address in different degrees. Thomas (2017) specified these forces as interest groups or pressure groups called sponsors like government and employers, providers, and consumers of professional services (Watson, 1992). The different influences of these forces, and the different degrees of response of the workers, reflect the words of Churchman and Woodhouse (1998) that several stakeholders influence education in entirety and their degree of influence varies.

The results of this study initially revealed that the vision, mission, goals, and objectives of an institution are some of the most powerful statements that serve as an internal factor that influence the curriculum and they are collectively addressed in the curriculum.

The widely known scholars of curriculum development, Tyler (1949) and Taba (1962) identified the philosophy of education and the nature of knowledge as two potent factors that should be considered in the continuous development of the curriculum. These factors are expressed in the vision, mission, goals, and objectives of the institution and are entrenched to the different levels of the institution. Michaud (2015) stated that there are numerous conceptual benefits to the practice of philosophy. Ornstein and Hunkins (2004) considered philosophy as an important base of the curriculum. They explained that the school philosophy has a great weight to the kind of goals and content of the curriculum. It also influences the way the curriculum is organized, which is the concern of design.

Furthermore, the results uncovered that a high regulating body or commission pushing external forces of quality assurance is well considered a factor that controls the quality of the curriculum through compliance to minimum standards.

Harman (1989) noted that some disciplines often encounter competing demands of the institution itself and the regulatory body. The institution in which the curriculum belongs demands for the quality of education while the regulatory body mostly for standards of the curriculum (Churchman $\&$ Woodhouse, 1998). The professional regulatory body nonetheless has the role to articulate the nature of the education required to enter to the profession; assess the competencies of the products; ensure suitable curriculum programs; and outline the education required for continued practice (Harvey, Mason, \& Ward, 2014).

On the other hand, the results of this work showed a somewhat inconsistency in compliance with the external demands of twenty-first century skills framework, board examination competencies, and education industry skills.

The sponsor stakeholders that influence the curriculum have a different degree of control depending on the context (Barnett, Becher, \& Cork, 1994). Considering the current study, there are three sponsor stakeholders like the government regulatory commission on higher education, the legislated body that administers the board examination, and the industry as a consumer of the professional services. These forces are mirrored in the recent studies that consider them as inputs in curriculum development (Klongvessa, 2011; Kim, 2012; Hegde \& Rao, 2015). Churchman and Woodhouse (1998) explained that in some professions with one sponsor stakeholder, the degree of pressure may be moderate. Thus, in the case of this study with many sponsor stakeholders, the degree of pressure may be high, potentially diffusing the effort of curriculum workers in different directions. This suggestive insight may help explain why there appeared to be a somewhat inconsistent response to these external influences in the curriculum. Aside from that informed assumption, this inconsistency may also mirror the different pushes and pulls from each of these forces to the curriculum rather than a harmonized one. 
Lastly, the accreditation council gained a notable discrepancy in whether its demand is being addressed in the curriculum or not. As the curriculum continues to submit itself to this external force, there is a need to ensure that inputs are treated into the curriculum, so that its influence will become more overt.

This very possible discrepancy as to how internal members address the influence of accreditation to the curriculum has roots to the traditionally rooted perspective that accreditation is not a major force affecting program design (Cohen \& Brawer, 1986). As an external pressure to the curriculum, accreditation is traditionally seen most often in the review of missions and goals (Simons, 1988). However, accreditation nowadays has evolved to encompass wide aspects of the program such as curriculum and instruction, faculty, library, physical resources, extension and community service, research, laboratory, and student services (Conchada \& Tiongco, 2015; Akarem \& Hossain, 2016)

\section{CONCLUSION}

The data transformative model under the triangulation mixed method research design, accounted for the development of two different data types into quantitative data set from the same sources. Furthermore, by directly comparing these transformed data, the model revealed possible points of agreement and discrepancy in the evaluations of the school administrators and teachers. Thus, in this aspect, it effectively compensated with the innate subjectivist weakness of internal evaluation.

This study contributes new knowledge regarding the applicability of the data transformative model in internal evaluation. It also presents pieces of evidence that may be considered to improve the curriculum program. This current internal evaluation research is formative focusing on the assessment of strengths and weaknesses to inform continuous improvement (Nelson, Ehren, \& Godfrey, 2017). Thus, an extension of this research continuing the tradition of data transformative model but progressively focusing on larger aspects of the curriculum should be further conducted.

\section{REFERENCES}

Akarem, H.S. \& Hossain, S.S. (2016). Determinants of education quality: what makes students' perception different? Journal Open Review of Educational Research, 3(1), 52-67. https://doi.org/10.1080/23265507.2016.1155167

Barnett, R., Becher R.A. \& Cork, N.M. (1987). Models of Professional Preparation: pharmacy, nursing, and teacher education. Studies in Higher Education, 12(1), 51-63. https://doi.org/10.1080/03075078712331378270

Churchman, R. \& Woodhouse, D. (1998). Professional, regulatory \& statutory bodies and higher education institutions [Monograph]. New Zealand Universities Academic Audit Unit, New Zealand. Retrieved from https://www.aqa.ac.nz/sites/all/files/ASQ1.pdf

Clifford, D.L. (1987). Consideration of simple measures and organizational structure. Evaluation and Program Planning 10(23), 1-237. https://doi.org/10.1016/0149-7189(87)90034-6

Cohen, A. M., and Brawer, F. B. (1986). The collegiate curriculum. Community College Review, 14(3), 13. https://doi.org/10.1177/009155218601400302

Conchada, M.I.P. \& Tiongco, M.M. (2015). A Review of the accreditation system for Philippine higher education institutions (Report No. 2015-30). Makati City: Philippine Institute for Development Studies.

Creswell, J.W. \& Plano Clark, V.L. (2011). Designing and conducting mixed methods research (2nd ed.). Los Angeles: Sage.

Giacquinta, J.B. (1998) Seduced and abandoned: some lasting conclusions about planned change from the Cambire school study. In A. Hargreaves et al. (eds.), International Handbook of Educational Change (pp.163-180). London: Kluwer Academic Publishers.

Greene, J.C. 2007. Is mixed methods social inquiry a distinctive methodology? Journal of Mixed Methods Research, 2(1), 7-22. https://doi.org/10.1177/1558689807309969

Harman, K.M. (1989). Professional versus academic values: Cultural ambivalence in university professional school in Australia. Higher Education, 18, 401-509. https://doi.org/10.1007/BF00138744

Harvey, L., Mason, S., \& Ward, R. (2014). The role of professional bodies in higher education quality monitoring. Birmingham: Author. 
Hegde, V.N. \& Rao, N. (2015). An outcome based curriculum design in engineering - Case study approach. Journal of Engineering Education Transformations, 29(2), 41-46. https://doi.org/10.16920/jeet/2015/v29i2/83041

International Education Systems (2017). Internal evaluation report. South Africa: Hout Bay International School. Retrieved from https:/houtbayinternational.co.za/wp-content/uploads/sites/2/2017/11/IQAA-Report2017.pdf

International University of Sarajevo (2018). Internal evaluation report. Sarajevo, Bosnia and Herzegovina: Faculty of Law. Retrieved from https://www.ius.edu.ba/sites/default/files/docs/appendix_9_internal_evaluation_report_faculty_of_law 2017-2018.pdf

Johnson, R.B. \& Christensen, L.B. (2017). Educational research: Quantitative, qualitative, and mixed approaches ( $6^{\text {th }}$ ed.). Los Angeles: Sage.

Jupp, V. (2006). The SAGE Dictionary of Social Research Methods. London: Sage Publications.

Kennedy, M.M. (1983). The role of the in-house evaluator. Evaluation Review, 7(4), 519-541. https://doi.org/10.1177/0193841x8300700406

Kim, H.S. (2012). Outcomes-based Curriculum Development and Student Evaluation in Nursing Education. Journal of Korean Academy of Nursing, 42(7), 917-927. http://dx.doi.org/10.4040/jkan.2012.42.7.917

Klongvessa, N. (2011, March). Outcome-based curriculum and alteration in landscape architecture lesson plan. Paper presented at IFLA APR Symposium on Landscape Architecture Education, Putra, Malaysia. Retrieved from http://www.land.arch.chula.ac.th/eng/service.php?catid=6

Kyoto University Graduate School of Management (2015). Internal assessment and evaluation report. Kyoto, Japan: Education Division. Retrieved from http:/www.kyotou.ac.jp/ja/about/evaluation/estimate/documents/nin-hyoka110329-3.pdf

Love, A.J. (1998). Internal evaluation: integrating evaluation and social work practice. Scandinavian Journal of Social Welfare, 7(2), 145-151. Retrieved from https://doi.org/10.1111/j.1468-2397.1997.tb00191.x.

Makaran, D. (2015). Factors influencing curriculum development process in secondary school education in Mogadishu, Somalia. (M.A. thesis). Retrieved from http://erepository.uonbi.ac.ke

Michaud, N. (2015). Why philosophy is important for administrators in education. Journal of Inquiry \& Action in Education, 6(3), 74-86. Retrieved from https:/files.eric.ed.gov/fulltext/EJ1133494.pdf

Moore, D. S., \& McCabe, G. P. (2005). Introduction to the practice of statistics $\left(5^{\text {th }}\right.$ ed.). New York: W.H. Freeman \& Company.

Nevo, D. (2001). School evaluation: internal or external? Studies in Educational Evaluation, 27(2), 95-106. https://doi.org/10.1016/S0191-491X(01)00016-5

Nelson, R., Ehren, M., \& Godfrey, D. (2017). Literature review on internal evaluation. [Review at Institute of Education University College London] Retrieved from http://www.schoolinspections.eu/wpcontent/uploads/downloads/2015/09/Literature-review-internal-evaluation.pdf

Norman, P.J. \& Sherwood, S.A.S. (2015) Using internal and external evaluation to shape teacher preparation curriculum: a model for continuous program improvement. The New Educator, 11(1), 4-23. https://doi.org/10.1080/1547688x.2015.1001263

Onwuegbuzie, A.J. \& Johnson, R.B. (2006). The "validity" issue in mixed research. Research in the Schools, 13, 48-63. Retrieved from https://www.semanticscholar.org/paper/The-Validity-Issue-in-Mixed-ResearchOnwuegbuzie-Johnson/6bfec4b77e5befdd1282de319b08294ba7913aaf

Ornstein, A.C. \& Hunkins, F.P. (2004). Curriculum: Foundations, principles, and issues (6 $6^{\text {th }}$ ed.). Boston: Allyn \& Bacon.

Peretz, M.B. (2003). Curriculum reform in Israel: The power of individuals and other forces. In J. Van den Akker et al. (eds.). Curriculum landscapes and trends (pp. 45-59). Dordrecht: Kluwer Academic Publishers.

Sellwood-Davis, S.C. (2016) An internal evaluation of a health program for adults with mild, moderate, and severe intellectual disabilities (Doctoral dissertation). https://doi.org/10.13023/ETD.2016.465

Simons, H.L. (1988). Accreditation and curricular change. In D.R. Wolf \& M.I. Zoglin (eds.). External influencer on the curriculum: new directions for community colleges (pp. 61-70). San Francisco: Jossry-Bass

Skilbeck, M. (1984). School-based curriculum development. London: Harper \& Row.

Suen, L.W., Huang, H., \& Lee, H. (2014). A comparison of convenience sampling and purposive sampling. Hu Li Za Zhi, 61(3), 105-111. https://doi.org/10.11648/j.ajtas.20160501.11

Taba, H. (1962). Curriculum development: Theory and practice. New York: Harcourt Brace Jovanovich.

Technological Educational Institute of Athens (2010). Internal evaluation report. Athens, Greece: Faculty of Management \& Economics, Department of Library Science and Information Systems. Retrieved from http://www.teiath.gr/userfiles/mdendr/documents/internal_evaluation_report_final_en_june2011.pdf

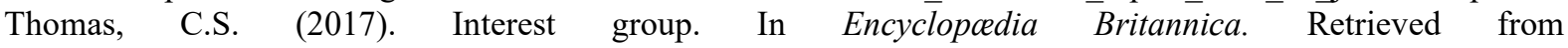
https://www.britannica.com/topic/interest-group 
Torchim, W. (2006). Descriptive Statistics. Web Center for Social Research Methods. Retrieved from https://socialresearchmethods.net/kb/statdesc.php.

Tyler, M.C. (2005) A fundamental choice: internal or external evaluation? Evaluation Journal of Australasia, 4(1), 3-11. https://doi.org/10.1177/1035719x05004001-202

Tyler, R.W. (1949). Basic principles of curriculum and instruction. Chicago: University of Chicago Press.

Vajargah, K.F., Babadi, A.K., \& Hajatmand, F. (2014). Evaluating the internal quality of educational programs of Ph.D. medical ethics curriculum from point of professors and students. Medical Ethics Journal, 8(27), 129-152. Retrieved from http://journals.sbmu.ac.ir/en-me/rt/printerFriendly/10176/0

Watson, D. (1992) The changing shape of professional education. In Bines, H. \& Watson, D., Developing professional education, Buckingham: SRHE and Open University Press

Yeung, S.S. (2010). Using school evaluation policy to effect curriculum change? A reflection on the SSE and ESR exercise in Hong Kong. Educational Research Journal, 25(2), 187-209. Retrieved from https://search.informit.com.au/documentSummary; $\mathrm{dn}=406753057990392$;res=IELHSS

Yusa, A., Hynie, M., \& Mitchell, S. (2016). Utilization of internal evaluation results by community mental health organizations: Credibility in different forms. Evaluation and Program Planning, 54, 11-18. http://dx.doi.org/10.1016/j.evalprogplan.2015.09.006 